\title{
The Effect of Problem Based Learning on Gifted and Normal Students' Achievement and Creativity Levels
}

\section{Esra KANLI* \& Serap EMİR}

\author{
İstanbul University, İstanbul, TURKEY
}

Received : 19.01 .2012

Accepted : 05.12.2013

Abstract - The aim of the research is to develop, administer and test the effects of a Science and Technology program for gifted and normal learners. The research has been carried on a pilot school in İstanbul which enrolls gifted and normal learners. The study group of the research consisted of 48 sixth graders, 25 of them were included in experimental group, and 23 of them were in the control group. In the experimental group, the students received a differentiated education about “Electricity In Our Lives” unit, whereas the students in control group received no intervention. The research data was derived from "Torrance Test of Creative Thinking" and "Achievement Test" which was developed by the researchers. Non-parametric MannWhitney-U and Wilcoxon Signed Rank tests were applied in order to analyze the statistical data. The findings of the research showed that the developed program increased the achievement levels of students and no difference observed for creativity.

Key Words: Science and Technology Education, Gifted Individual, Problem-based Learning, Creativity. DOI No: http://dx.doi.org/10.12973/nefmed201

\section{Summary}

Purpose and Significance: The proposed research aimed to determine the effects of a science and technology program, which has been differentiated for gifted learners and used problem based learning as a theoretical base, on students' achievement levels in learning science and general creativity scores. It has been considered that the differentiated education which is appropriate for gifted learners cognitive skills and demands is important for their development. Differentiation has four aspects and problem based learning is used for process

\footnotetext{
* Corresponding author: Esra KANLI, Res. Assist..in Department of Special Education Division Gifted Education, Istanbul University, HAY Faculty of Education, Istanbul, TURKEY.

E-mail: ekanli@istanbul.edu.tr
}

Note: This study is a part of Esra KANLI's M.A. dissertation. 
differentiation. Furthermore, related literature claims that problem based learning has positive effects on creativity which is accepted as an important facet of giftedness. In this context the findings of the research, that has positive effects on students' achievement and creativity levels is considered to be important for science and gifted education.

Methodology: Experimental research methodology has been used in the study. The study group of the research constituted from 48 students, 25 of them were in the experiment group and 23 of them were in the control group. The Achievement Test which is developed by the researchers and Torrance Test of Creative Thinking was applied as a pre-post test to the study group. After the assessment of the pre test scores, in the experiment group, the students received a differentiated education about the unit “Electricity In Our Lives", whereas the students in control group received no intervention and continued their regular education with their regular science and technology teacher. After the completion of the treatments the above mentioned tests have been administered again to the both of the groups as a post test. Then the collected data was analyzed using appropriate statistical techniques.

Results: The results of the study showed that achievement test's scores of the groups differed at the end of the study whereas no significant difference observed between the groups regarding the creativity scores. For the achievement test, significant differences was observed between experimental and control groups for post-test and advancement scores $(p<.01)$, whereas there were no differences in creativity between groups' post tests and advancement scores when two groups was compared with each other. However, significant differences was observed in in-group advancement scores, both for experimental and control groups (respectively; $\mathrm{p}<.01 ; \mathrm{p}<.05$ ). Further analyses of the data showed that the gifted and normal students advancement scores for creativity test were statistically significant in experimental group ( $\mathrm{p}<.01$ ), whereas in control group only gifted students showed a statistically significant advancement in creativity test scores $(\mathrm{p}<.05)$ and this difference was slightly lower than the experimental groups' scores.

Discussion and Conclusions: The statistically significant difference observed between the post test scores of the group's achievement tests showed that differentiated unit has positive effects on students' learning. Differentiation of the unit was done by taking problem based learning as a basis, which means that problem based learning is an appropriate differentiation technique that can be used while working with gifted students as well as average ones. However, significant differences couldn't be found for the creativity post-test and between groups advancement scores, whereas statistically significant differences observed in in-group 
advancement scores. It can be argued that problem based learning didn't increase the creativity levels of students; however, this study was carried on a special group who has been receiving creativity education for 6 years, so it can be said that this education diminished the pre existing differences about creativity. Although post test scores about creativity wasn't significant, experiment group advanced more than the control group, which can be interpreted as problem based learning has positive effects on creativity levels of students. All those above mentioned results states that; the usage of appropriate curriculum and teaching techniques is important for the achievement and creativity of students. 


\title{
Probleme Dayalı Fen ve Teknoloji Öğretiminin Üstün Zekalı ve Normal Öğrencilerin Başarı ve Yaratıcı Düşünme Düzeylerine Etkisi
}

\section{Esra $\mathrm{KANLI}^{\dagger}$ ve Serap EMİR}

\author{
İstanbul Üniversitesi, İstanbul, Türkiye
}

Makale Gönderme Tarihi: 18.01.2012

Makale Kabul Tarihi: 05.12.2013

Özet - Araştırmada, farklı bilişsel özelliklere sahip üstün zekâlı öğrencilere yönelik onların akademik beklentilerini karşılayacak bir Fen ve Teknoloji programının geliştirilmesi, uygulanması ve etkililiğinin sınanması amaçlanmıştır. Çalışma, İstanbul'da, üstün zekâlı çocuklara farklılaştırılmış bir eğitim programı sunan bir proje okulunda, 6. sınıfa devam eden 25'i deney, 23'ü de kontrol grubundaki toplam 48 öğrenci ile gerçekleştirilmiştir. Deney grubundaki öğrencilere "Yaşamımızdaki Elektrik" ünitesi boyunca probleme dayalı öğrenmeyi temele alan farklılaştırılmış program uygulanırken kontrol grubundaki öğrencilerin öğrenmeöğretmen süreçlerine herhangi bir müdahalede bulunulmamıştır. Verilerin toplanması için araştırmacılar tarafından geliştirilen "Başarı Testi” ve "Torrance Yaratıcı Düşünme Testi” kullanılmıştır. İstatistiksel analizlerde non-parametric Mann Whitney-U testi ve Wilcoxon İşaretlenmiş Mertebeler Testi teknikleri kullanılmıştır. Araştırmanın bulgularına göre, üstün zekalı öğrencilere yönelik hazırlanan program öğrencilerin başarısını arttırırken, yaratıcı düşünme düzeylerini anlamlı düzeyde etkilememiştir.

Anahtar Kelimeler: Fen ve Teknoloji Öğretimi, Üstün Zekâlı Birey, Probleme Dayalı Öğrenme, Yaratıcılık.

\section{Giriş}

Bir toplumun ilerlemesi ve çağdaşlaşması için bilim ve teknolojideki ilerlemelere uyum sağlaması ve daha önemlisi bu yenilikleri üretmesi gerekmektedir. Günümüz dünyasında bireylerden beklenen önceki yüzyıllarda olduğu gibi bilgiyi zihninde depolayan kişiler olmalarından ziyade bilgiyi kullanabilen kişiler olmalarıdır. Bireylerin bilgiyi kullanabilme becerisini kazanabilmeleri ise ancak ve ancak planlı ve sistemli bir eğitim ile mümkün olabilmektedir .

\footnotetext{
$\dagger$ İletişim: Esra KANLI, Arş. Gör., Özel Eğitim B1., Üstün Zekalılar Eğitimi A.B.D., İstanbul Üniversitesi, HAY Eğitim Fakültesi, İstanbul, TÜRKIYE

E-posta: ekanli@istanbul.edu.tr

Not: Bu çalışma Esra KANLI'nın yüksek lisans tezinin bir bölümüdür.
} 
Eğitim sistemleri içerisinde hedeflenen bilgi üretme kapasitesine en fazla sahip olduğu düşünülen gruplardan bir tanesi de üstün zekalı ve yetenekli bireylerdir. Üstün zekalı bireyin nasıl tanımlanacağı üzerinde araştırmacılar tıpkı zeka kavramındaki gibi ve alakalı olarak bir fikir birliğine ulaşamamışlardır. Var olan tanımlardaki en temel ortak noktalar ise üst düzey düşünebilme becerisi, motivasyon ve yaratıcılık gibi kavramlardır. 1972'de yayınlanan Marland Raporunda yer alan çokyüzlü tanım o günden beri yaygın olarak kullanılmaktadır. Rapora göre üstün zekalı ve yetenekli birey alışılmamış üstün yetenekleri sayesinde yüksek performans gösterebilen bireydir. Bu çocukların kendi potansiyellerini anlamaları, kendilerine ve topluma katkıda bulunabilmeleri için normal okullarda verilen eğitimin ötesinde farklılaştırılmış bir eğitim programına ihtiyaçları vardır. Üstün performans gösteren bireyler genel zihinsel yetenek, özel akademik yetenek, yaratıcı veya üretken düşünme, liderlik yeteneği, görsel ve performansa dayalı sanat yeteneği, psikomotor yetenek gibi özelliklerin biri ya da birkaçının kombinasyonlarını gösterirler.

Maker (2003) ise, üstünlüğün sadece yüksek zeka bölümü ile değerlendirilmesine karş1 çıkmış ve bunun üstünlük tanımını daraltarak kavramın zenginliğini ifade edemediğini belirtmiştir. Maker'a göre (2003), üstünlüğün temel bileşenleri arasında ilgiler, istekler ve karmaşık problemleri çözme yeteneği bulunmaktadır.

VanTassel-Baska (2003), üstünlüğü şöyle özetlemektedir; eğer zeka üst basamaklardaki problemleri çözme, belirli bir alanda üstün düzeyde uzmanlık, bir kişinin çalışmasını yansıtıcı bir biçimde planlama, gözlemleme ve değerlendirme kapasitesini içeriyorsa, üstünlük bu becerileri kendi yaşıtlarına göre daha üst seviyelerde gösteren bireylerin özelliğidir. Daha basit bir ifadeyle üstünlük bütün zihinsel alanlarda veya spesifik bir alanda ileri düzeyde gelişmişlik veya istenilen sonucu elde etmek için ortaya konulan alışılmamış örgütleme gücü olarak da tanımlanabilir.

\section{Üstün Zekalı ve Yetenekli Öğrencilerde Fen Bilimleri Ĕ̆itimi}

Üstün zekalı ve yetenekli bireyler sahip oldukları bilişsel, duyuşsal ve gelişimsel özelliklerindeki farklılıklardan dolayı kendilerine has özelliklerine ve ihtiyaçlarına uygun bir eğitime ihtiyaç duyarlar. Üstünlüğün tanımında var olan çeşitlilik üstün zekalı ve yetenekli öğrencilerin eğitimi konusunda da kendini göstermektedir. Eğitimciler üstün zekalı ve yetenekli bireyin ilerlemesine nasıl yardımcı olabilirler? Bu cevabı oldukça zor olan bir sorudur, zira üstün bireylerin hayatlarını etkileyen şeylerle ilgili yapılan araştırmalar çoğunlukla ailenin rolü, motivasyon gibi içsel faktörlerin rolü, kristalize deneyimlerin rolü, istek ve amaçların rolü veya şansın rolü gibi olgularla ilişkilidir (VanTassel-Baska, 2000). 
Fen bilimlerindeki yetenek gelişiminin süreci, bir bilim insanı olma yolundaki süreci yansıtmaktadır. Piirto (2004), yetenek gelişimini bilişsel kapasite, genetik ve kişisel özelliklerin aile, okul ve toplum tarafından etkilenen çok yüzlü bir fenomen olarak görmektedir. Albert (1980) ise üstünlüğe erişmek için iki transformasyonun olması gerektiğini ileri sürmüş ve ilkini akademik üstünlüğün yaratıcı üstünlüğe dönüştürülmesi, ikincisini ise yaratıcılığın başarıya götüren yetenek, güdü ve değerlere dönüştürülmesi olarak ifade etmiştir (aktaran Pyryt, 2000). Fen bilimleri alanında üstün yetenek sahibi bireylerin tanılanması onlara doğru eğitimin verilebilmesi adına büyük önem taşımaktadır. Fakat tanılama sürecindeki zorluklardan bir tanesi yetenek ve potansiyelin ayrıştırılmasıdır. Tanılamadaki bir diğer zorluk ise insanların fen ile ilgili sahip oldukları örtük fikirlerdir. Birçokları için fen bilimlerinde üstünlüğe sahip olmak demek çok sayıda enteresan fenomeni biliyor olmak demektir. Mesela dinozorlarla çok ilgili olan onların bütün isimlerini sayabilen bir çocuk genellikle üstün olarak nitelendirilir, fakat bu tek başına yeterli değildir. Asıl önemli olan bilgiyi bulma ve kullanma yönündeki tutku ve becerilerdir (Watters, 2004).

Watters'in (2004), Roeper (1988), Rakow (1998) ve Waters \& Diezmann'dan (1997), derlediğine göre fen bilimleri alanında üstün yetenekli olan öğrencilerin özellikleri şunlardır;

- Fenomenlerin anlamlarını ve açıklamalarını araştırırlar

- Dünyadaki kaosa, yaşam ve ölümde dahil olmak üzere çevrelerine karşı duyarlıdırlar ve farkındalıkları yüksektir

- Doğal fenomenleri soyut yollarla kategorize ederler

- Genellikle fen bilimleri ile ilgili bir alana karşı çok ilgilidirler ve bu alandaki kavramları araştırmak ve incelemek konusunda 1srarcıdırlar

- Koleksiyon yapmaya (böcek, taş..vs.) ilgilidirler

- Objeleri parçalamaya ve tekrar bir araya getirmeye çalışırlar

- Çevrelerindeki şeylerin kökenlerine karşı meraklıdırlar

- Görsel uzamsal yeteneklere sahiptirler

- İlgi alanlarında uzman olan kişilere ulaşmaya çalışırlar

- Kendi fikirlerini açıklarken gergin ve sabit fikirli olabilirler.

Üstünlerin eğitimi ile ilgili alan yazın incelendiğinde bir çok model, eğitimlerinde takip edilecek stratejiler ve öneriler bulunsa da fen bilimleri alanında uygulanmış ve etkinliği ispatlanmış çok az örnekle karşılaşmaktayız. Üstün zekalı ve yetenekli öğrencilerin okullardaki yaşantılarına ilişkin veriler onların okullarda ihtiyaçları olan eğitimi alamadıkları 
yönündedir. Geleneksel şekilde işlenen fen ve matematik eğitim programı üstün öğrenciler için uygun değildir çünkü çok fazla tekrar içermektedir ve öğrencilere derinlemesine öğrenme imkanı tanımamaktadır (Johnson, Boyce \& VanTassel-Baska, 1995). Johnsen ve Ryser (1996) normal sınıflarda eğitime devam eden üstün zekalı öğrenciler için 5 farklılaştırma alanı olabileceğini belirtmiştir. Bunlar; içeriği modifiye etmek, öğrencilerin tercihlerine dikkate almak, öğretimin hızını değiştirmek, esnek bir sınıf ortamı yaratmak ve spesifik öğretimsel stratejileri kullanmaktır. Öğrencilerin başarısını arttıran, eleştirel ve yaratıcı düşünmeyi destekleyen öğretimsel stratejileri kullanmanın üstün zekalı bireylerin eğitimindeki en önemli noktalardan biri olduğunu vurgulayan pek çok araştırma bulunmaktadır (Johnsen \& Ryser, 1996). Stepanek (1999) ise üstün zekalı ve yetenekli bireylerin fen ve matematik eğitimlerinde süreci farklılaştırmak için öz-denetimli öğrenme, öğrenme merkezleri, probleme dayalı öğrenme ve seminerlerin kullanılabileceğini belirtmektedir.

\section{Probleme Dayalı Öğrenme}

Probleme dayalı öğrenme (PDÖ), Kilpatrick ve Dewey’in düşünceleri üzerinden gelişmiş ve eğitim ortamlarında uzun yıllardır kullanılan bir öğrenme yaklaşımı olarak, öğrenmede gerçek yaşam problemlerine odaklanmaktadır (Yaman \& Yalçın, 2005). Probleme dayalı öğrenme yaklaşımı öğrencilerin okulda edindikleri bilgi ve becerileri problem çözmede kullanarak gerçek yaşam problemlerine aktarımda bulunmalarına ve bu bağlamda deneyim kazanmalarına yardımcı olur (Hmelo-Silver, 2004). Ayrıca öğrenciler problem çözme ve öğrenme sürecinde doğrudan yer alarak aktif öğrenme şansı elde ederler (Sönmez \& Lee, 2003; Chin \& Chia, 2004). Alan yazında yapılmış olan çalışmalar öğrenme sürecine doğrudan ve etkin şekilde katılan öğrencilerin daha anlamlı bir öğrenme gerçekleştirdiklerini ifade etmektedir (bkz. Harris ve diğ., 2001).

Probleme dayalı öğrenme öğrencilere farklı disiplinlerde araştırma yapma, deneyim edinme ve problem çözme olanakları tanıyarak etkili problem çözme becerileri geliştirmelerini sağlamasının yanı sıra ve disiplinler arası etkileşimler ve işbirlikli çalışmalara da olanak sağlaması nedeniyle farklı bir öğretim yaklaşımı olarak değerlendirilebilir (Karamustafaoğlu \& Yaman, 2006).

PDÖ’nün karakteristik özellikleri arasında öğrenmeye rehberlik etmesi için kullanılan yapılandırılmamış problemler kullanılması, öğretmenin biliş ötesi mentör olarak hareket etmesi ve öğrencilerin işbirlikli öğrenme grupları içerisinde çalışması sayılabilir. Yapılandırılmamış problemler ilk durumun çözüme ulaşmak için yeterli ve gerekli bilgiyi 
içermediği ve tek bir doğru çözümün olmadığı problemlerdir. Öğrenciler PDÖ’de gerçek yaşamı temel alan sorunlar üzerinde çalıştıkları için, okulda öğretilen fen bilimleri ile gerçek yaşamda karşılaşılan sorunları çözmek için kullanılacak olan fen bilimleri bilgileri arasında daha iyi bağlantılar kurabilirler.

Probleme dayalı öğrenme süreci temelde dört bileşenden oluşmaktadır. Bunlar; problem veya problem senaryoları, öğrenci, eğitim yönlendiricisi ve değerlendirmedir. Bu bileşenlerin hepsi doğru şekilde örgütlenebilir ve birbirinin tamamlayıcısı olursa sürecin etkinliği artar. Probleme dayalı öğrenme Dewey’in üzerinde önemle durduğu araştırmanın altı özelliğine de uygun bir yapı içermektedir. Bu özelliklerden birincisi, öğrencilerin karşılaştıkları şüpheli bir durumun olmasıdır. Bu, belirsiz, kafa karıştırıcı, açık bir çözümü olmayan durumdur. İkincisi, PDÖ içeriğinin, bir teşhis yapmak için çözülecek problemin düzenlenmesidir. Üçüncüsü, başkaları tarafından yapılan önceki çalışmalar hakkında bilgi edinmektir. Dördüncüsü, eldeki bilgiler hakkında bir hükme varmak için mevcut alternatifleri kullanarak bir nedenler süreci ortaya çıkarmaktır. Beşincisi, çözümün kavramsal ve deneysel öğelerinin ortaya konmasıdır. Altıncı özellik ise bilimsel ve mantıklı bilgiler arasındaki ilişkinin araştırmaya uygun olmasıdır (Roschelle, 1999). Birey bu özelliklerin hepsini doğru bir şekilde uygulamayı başardığında araştırma amacına ulaşacak ve anlamlı öğrenme meydana gelecektir.

Ngeow ve Kong'a (2001) göre probleme dayalı öğrenme etkinliklerinde yer alan öğrenciler kendi öğrenmelerinden daha sorumludurlar, fakat bazıları için öz denetimli öğrenme zorlayıcı olabilir. İşbirlikli öğrenme probleme dayalı öğrenmenin en önemli parçalarından biridir ve öğrenciler bu öğrenme gruplarının içerisinde verimli şekilde yer almayı öğrenmelidirler.

Probleme dayalı öğrenmenin avantajlarından biri olan ve öğrenme ürünlerinde de karşımıza çıkan yaratıcılık öğrencilerin sahip olmasını istediğimiz en önemli özelliklerden bir tanesidir. Özellikle yeni ve olası sorunlara çözüm üreten, yeni ürünler ortaya koymaya çalışan fen bilimleri için yaratıcı düşünme becerisi önem taşımaktadır. Bu bağlamda probleme dayalı öğrenme yöntemi sayesinde yaratıcı düşünmenin desteklenmesi, yöntemin özellikle üstün zekalı ve yetenekli bireyleri de içeren gruplarda işe koşulması adına önem arz etmektedir.

\section{Yaratıcılık}

Yaratıcılık belirli bir alanla ya da eylemle sınırlı değildir. Öyle ki bir birey bir resmi yeni bir şekilde renklendirirken, bir melodi bestelerken yahut yeni bir bilimsel teori ortaya koyarken yaratıcı olabilir. Son yıllarda yaratıcılığın günümüz dünyası için öneminin daha fazla anlaşılmasıyla birlikte yaratıcılıkla ilgili yapılan çalışmaların sayısında büyük bir artış 
kaydedilmiştir. $\mathrm{Bu}$ çalışmalar yaratıcılık için kabul edilmiş ortak bir tanım ortaya koyamasalar da yaratıcılığın nelerden oluştuğunu açıklamaya çalışmaktadırlar.

Günümüzde yaratıcılık genellikle ilgili ve soyut fikirlerin üretimi olarak tanımlanmaktadır (aktaran Cropley \& Urban, 2000). Yaratıcılıkla ilgili yapılan tanımlardaki tek ortak noktanın yenilik (novelty) olduğunu görmekteyiz. Bu verimli ve etkili yenilik problemin belli yapılarının analiz edilmesi, erişilebilir olan bilgilerden uygun olanların seçilmesi, öncül ve yeni bilgilerin parçalarının birleştirilmesi, ortaya yeni çıkan kombinasyonların değerlendirilmesi, başarılı olan kombinasyonların seçilmesi ve sonuçların diğerleriyle paylaşılmasını içerir. Clark (2002), yaratıcılığın duygusal ve sezgi olmak üzere iki farklı boyut üzerinden incelenebileceğini ve bu boyutlar bağlamında yaratıcılığı duygusal açıdan değerlendirilenlerde mutlu olma ve kendini gerçekleştirme, sezgisel açıdan değerlendirenlerde ise olayları anlamanın sadece mantıki kıyaslarla mümkün olmayacağı ve hissedilenlerin önem taşıdığı görüşü ağır basar.

Yaratıcılık çağrışımsal teoride de ifade edildiği üzere mevcut bilgiler arasındaki benzerliklerden yararlanarak yeni ve farklı fikir ve çözümlerin üretilmesi olarak da tanımlanabilir. Yaratıcı düşünme becerisi eğitimle geliştirilebilen bir beceridir. $\mathrm{Bu}$ bağlamda yaratıcılık eğitimi ne kadar erken bir dönemde başlarsa bireylerin yaratıcı düşünme potansiyellerinin geliştirilmesi o kadar mümkün olur. Probleme dayalı öğrenme yaklaşımında öğrencilerden beklenen gerçek yaşam problemlerine farklı çözümler bulmalarıdır. Kendilerine sunulan gerçek yaşam problemleri üzerinde fikir yürütürken öğrencilerin yaratıcı düşünme becerilerinin geliştiği söylenebilir.

Birçok farklı açıdan bakıldığında fen eğitiminin günümüz dünyasının en önemli alanlarından biri olduğunu görmekteyiz. O halde yaratıcı ve yetenekli öğrencilerimizi fen bilimleri alanlarında kariyer yapmaları için yönlendirmenin modern hayatın ve dünyanın iyiliği için kaçınılmaz olduğunu düşünmek yanlış olmaz. Üstün zekalı ve yetenekli bireyler fen bilimlerine karşı genellikle bir iç motivasyona sahiptirler. Bu sebepten onların bu alanda tanılanıp ihtiyaçları olan uygun eğitimi almalarının sağlaması sadece ülkemiz için değil tüm insanlık için gereklidir.

$\mathrm{Bu}$ bağlamda mevcut çalışmanın amacını üstün zekalı öğrencilere yönelik olarak ve probleme dayalı öğrenmeyi merkeze alarak geliştirilmiş bir fen ve teknoloji ünitesinin üstün ve normal öğrencilerin başarı ve yaratıcılıklarını nasıl etkilediğinin ortaya konulması oluşturmaktadır. Bu temel amaç doğrultusunda araştırmanın alt amacı, Fen ve Teknoloji dersinde probleme dayalı öğrenmenin uygulandığı grubun erişi ve yaratıcı düşünme puan 
ortalamaları ile kontrol grubunun erişi, yaratıcı düşünme puan ortalamaları arasında anlamlı bir farkın olup olmadığını ortaya koymaktır. Geliştirilen farklılaştırılmış program üstün zekalı öğrencilere yönelik farklılaştırma ilkelerini temel almakla birlikte dersler üstün ve normal zekalı öğrencilerden oluşan bir grupla birlikte yürütüldüğü için farklılaştırma yöntem ve teknikleri her iki grubunda ilgilerini çekecek ve ihtiyaçlarını karşılayacak şekilde planlanmıştır.

\section{Yöntem}

Araştırmada yarı deneysel deney-kontrol gruplu ön-test son-test deneme modeli kullanılmıştır. Araştırma deney ve kontrol olmak üzere iki grup üzerinde gerçekleştirilmiştir. Gruplar random-yansız atama yoluyla deney ve kontrol grubu olarak atanmışlardır.

\section{Çalışma Grubu}

Araştırma üstün zekalı öğrencileri de içeren özel bir grup üzerinde gerçekleştirilmiştir. $\mathrm{Bu}$ sebepten çalışmaya başlanmadan önce çalışma grubu belirlenirken yakınlık ve erişim kolaylığı sağlaması bakımından amaçlı örnekleme yöntemlerinden kolay ulaşılabilir örnekleme yöntemi (Yıldırım \& Şimşek, 2008) benimsenmiştir. Araştırma üstün ve normal öğrencilerin birlikte eğitim gördüğü bir proje okulunun 6. Sınıf düzeyindeki iki şubesinde eğitim gören üstün ve normal zeka düzeyindeki öğrenciler üzerinde gerçekleştirilmiştir. Çalışma Fen ve Teknoloji dersi "Yaşamımızdaki Elektrik" ünitesinde uygulanmıştır. Çalışmanın uygulamaya başlanmasından önce iki şubede bulunan öğrenciler 5. sınıf karne notu, 6. sınıf birinci dönem karne notu, 6. sınıf birinci dönem fen ve teknoloji dersi notu, başarı testi ve yaratıcı düşünme testi değişkenleri açısından karşıllaştırılmışlardır. Yapılan analizler sonucunda grupların belirtilen değişkenler açısından aralarında istatiksel olarak anlamlı bir farklılık bulunamamıştır. Ayrıca gruplar cinsiyet ve zeka değişkenleri açısından da incelenmiş ve grupların bu değişkenler açısından da benzer bir dağılım gösterdiği gözlenmiştir. Bu durum denel işlem başlamadan önce grupların birbirlerine denk olduğunu göstermektedir. Çeşitli değişkenler açısından birbirine denk olan iki şubeden biri deney diğeri ise kontrol grubu olarak random şekilde atanmıştır.

\section{Programın Hazırlanması ve Uygulanışı}

Çalışmada deney grubuna uygulanacak program hazırlanırken üstün zekalı ve yetenekli öğrencilere yönelik program farklılaştırma ilkeleri göz önünde bulundurularak çeşitli programlar incelenmiş ve incelenen programlardan faydalanılarak mevcut program 
geliştirilmiştir. Geliştirilen program Milli Eğitim Bakanlığının "Yaşamımızdaki Elektrik" ünitesi kazanımları ve farklılaştırılmış programın kazanımları bütünleştirilerek oluşturulmuştur. Kazanımlar oluşturulurken içerik, öğrenme-öğretme süreçleri ve değerlendirme boyutları yeniden yapılandırılmıştır. Hazırlanan farklılaştırılmış program sadece deney grubunda uygulanırken kontrol grubunun öğrenme-öğretme sürecine herhangi bir müdahalede bulunulmamıştır. Bu bağlamda kontrol grubunda bulunan öğrenciler, fen ve teknoloji öğretmenleri ile birlikte MEB eğitim programı ve kazanımları dahilinde eğitimöğretim faaliyetlerini devam ettirmişlerdir. Farklılaştırılmış program "sistemler" teması çevresinde ve probleme dayalı öğrenme yöntemi kullanılarak hazırlanmıştır. Dersler işlenirken şu yollar izlenmiştir. Konular işlenmeden önce deney grubuna araştırmada kullanılan probleme dayalı öğrenme modeli hakkında bilgi verilmiş ve onların da bu modeli tanımaları sağlanmıştır. Probleme dayalı aktif öğrenme modeli senaryolardan oluşmaktadır. Bu doğrultuda "Yaşamımızdaki Elektrik" ünitesi ile ilgili gerçek yaşamda karşılaşılan bir problem alanı seçilmiş ve senaryo haline getirilmiştir (Bkz. Ek 1). Ünite süresinde ilk kullanılan senaryo zenginleştirilip, farklılaştırılarak ve konu içerikleri bağlamında yeni senaryolar eklenerek eğitim-öğretim faaliyetlerine devam edilmiştir. Ünite boyunca bu temel probleme çözüm bulmak adına "Neler biliyoruz?", "Neleri öğrenmeye ihtiyacımız var?, ve "Bunları nasıl bulabiliriz?” sorularını temele alarak çalışılmıştır.

Deney grubunda 5 - 6 kişilik çalışma grupları oluşturulmuştur. Bu çalışma gruplarının oluşturulmasındaki temel amaç üstün ve normal zekalı öğrencileri barındıran sınıfta öğrencilerin ihtiyaçlarına hitap edebilecek eğitimin verilebilmesi için esnek grupların oluşturulabilmesidir. Deney grubu probleme dayalı öğrenme ile ilgili bilgi aldıktan sonra ilk oturumda grupların geneli ile birlikte sistem teması üzerinde durulmuş ve sistemler teması üzerinden elektrik sistemleri hakkında tartışılmıştır. Sonraki oturumda öğrencilere herhangi bir bilgi sunulmadan tüm grup üyelerine problem senaryosu dağıtılmış ve tartışılmıştır. Öğrencilere problemi incelemeleri için yeterli zaman tanındıktan sonra problem üzerinde konuşulmuş ve "Öğrenmemiz Gerekenler” tablosu üzerinde çalışmaları istenmiştir. Sonraki oturumda, tüm grup üyelerine ek problem cümlesi bilgisi dağıtılmış ve böylelikle PDÖ oturumlarında benimsenmiş olan "Neler biliyoruz?", "Neleri öğrenmeye ihtiyacımız var?, ve “Bunları nasıl bulabiliriz?” soruları üzerine odaklanılmış ve öğrenci çalışmaları bu minval üzere yönlendirilmiştir. Sonraki oturumlarda Öğrenmemiz Gerekenler tablosu temele alınmış ve probleme çözüm bulmak için öğrenilmesi ve araştırılması gereken alanlar üzerinde yoğunlaşılmıştır. Probleme çözüm bulmak için sadece sınıf içerisinde farklı öğretim 
etkinlikleri kullanılmakla yetinilmemiş probleme dayalı öğrenmenin en önemli özelliklerinden biri olan öğrencilerde yaşam boyu öğrenme ve öz-denetimli öğrenme becerisini geliştirmek için okul dışında yapılan araştırmalar desteklenmiş ve yönlendirilmiştir. Sürecin sonunda her grup problem senaryosuna bulduğu çözümü inşa ettikleri modellerde uygulamış ve ürünler sınıfa sunulmuştur. Değerlendirme kapsamında öğretmen değerlendirmesinin yanında öz-değerlendirme ve akran değerlendirmesi de kullanılmıştır. Bu modelle öğrencilerin derse aktif katılımı sağlanmıştır. Denel işlem bir ay boyunca ve 20 ders saati süresince devam ettirilmiştir.

\section{Veri Toplama Araçları}

Araştırmanın denencelerini test etmek üzere çoktan seçmeli sorular ve uzun cevaplı sorulardan oluşan başarı testi ve yaratıcı düşünme testi olmak üzere iki çeşit ölçme aracı kullanılmıştır.

Başarı Testi: Araştırmacılar tarafından, hazırlanan programın kazanımları dikkate alınarak geliştirilmiştir. Öncül sorular hazırlandıktan sonra uzman görüşleri alınmış ve yapılan revizyonlardan sonra testin geçerliğini belirlemek üzere ön deneme uygulaması gerçekleştirilmiştir. Bu uygulamaya öğretilecek olan kavramları bilen ve bilmeyen öğrencileri ayırt etmesi amacıyla bu dersi alıp geçmiş olan 7. sınıf öğrencileri ile hiç almamış olan 5. sınıf öğrencilerinden oluşan toplam 264 öğrenci katılmıştır. 264 öğrencinin çoktan seçmeli teste verdikleri cevaplar Itemann Madde ve Test Analiz programıyla analiz edilmiştir. Analiz sonucunda ayırıcılık gücü .40 'ın üzerinde olan maddeler başarı testinin son formunda yer almak üzere seçilmiştir. Bu yolla oluşturulan çoktan seçmeli sorulardan oluşan testin içerisinde 35 adet soru yer almıştır. 35 maddeden oluşan testin KR-21 güvenirlik katsayı .91 olarak hesaplanmıştır.

Açık Uçlu Sorular : Başlangıçta, araştırmacılar tarafından "Yaşamımızdaki Elektrik" ünitesinin konularını kapsayan ve öğrencilerin üst düzey düşünme becerilerini işe koşmalarını sağlamayı amaçlayan 20 adet açık uçlu soru oluşturulmuştur. Daha sonra soruların kapsam geçerliliğin sağlanması adına, 3 Fen ve Teknoloji öğretmeni, 2 Fen Bilgisi öğretimi öğretim üyesi, 2 program geliştirme uzmanı, 1 ölçme değerlendirme uzmanı ve 1 üstün zekalı ve yetenekliler eğitimi uzmanı olmak üzere toplam 9 uzman kanısı alınmıştır. Uzmanların yaptıkları yorum ve öneriler dahilinde essay tipi soruların sayısı 10'a düşürülmüştür. Başarı testinin ikinci kısmını oluşturan uzun cevaplı soruların değerlendirilmesi için ise öncelikle ayrıntılı cevap anahtarları oluşturulmuş ve puanlama kriterleri (10 üzerinden) belirlenmiştir. 
Öğrencilerin sorunlara yaratıcı çözümler sunma becerilerini ölçmeye dönük olan 3 soru dışında kalan 7 adet uzun cevaplı soru bu cevap ve puanlama anahtarları kullanarak değerlendirilmiştir. Öğrencilerin ortaya konan problemlere yaratıcı çözümler sunma becerileri ile ilgili olan 3 soru ise yaratıcı düşünmenin alt boyutlarından olan akıcılık, özgünlük, esneklik ve açıklayıcılığa göre araştırmacı tarafından değerlendirilmiştir. Yaratıcı düşünmenin yapısı gereği bu üç sorunun da alabileceği puanlar sabit değildir. Değerlendirme işlemine başlamadan önce deney ve kontrol gruplarının hem ön hem de son testte bu üç soruya verdikleri cevaplar tek tek okunmuş ve kriterler belirlenmiştir. Bunun yapılmasındaki amaç yaratıcılığın özgünlük boyutunun grup içerisinde değerlendirilmesini sağlamaktır. Puanlayıcı güvenirliğini sağlamak adına ise (intra-rater reliability) araştırmacı 3 hafta arayla her iki grubunda ön ve son testlerdeki uzun cevaplı sorularını değerlendirmiş ve bu iki farklı zamanda verilen puanların aritmetik ortalamaları alınarak analizlere dahil edilmiştir.

\section{Yaratıcı Düşünme Testi}

Deney ve kontrol grubunun yaratıcı düşünme yeteneklerini ölçmek için E. Paul Torrance (1966) tarafından geliştirilmiş olan "Torrance Yaratıcı Düşünce Testi-TYDT" kullanılmış ve yaratıcı düşünme ile ilgili veriler elde edilmiştir. Torrance Yaratıcı Düşünce Testi A formu ve B Formu olmak üzere iki adet paralel formdan oluşmaktadır. Torrance Yaratıcı Düşünce Testi'nin "A" formu denel işlem başlamadan önce, "B" formu ise denel işlem tamamlandıktan sonra her iki gruba da verilmiştir. TYDT’nin uygulaması norm ve kriter dayanaklı ölçütlerini kapsayan yönergeler doğrultusunda yapılmıştır. Torrance Yaratıcı Düşünce Testi'nin her iki formu da "sözel” ve "şekilsel” kısımlardan oluşmaktadır. Sözel kısım 7 alt test, şekilsel kısım ise 3 alt test olmak üzere test toplamda 10 adet alt testten oluşmaktadır. Mevcut çalışmada Torrance Yaratıcı Düşünce Testi”nin A ve B formlarının sözel kısımları kullanılmıştır.

TYDT'nin dilsel eşdeğerlik, geçerlik ve güvenirlik çalışmaları Aslan tarafından 2001 yılında gerçekleştirilmiştir. TYDT’nin sözel kısmı için Cronbach alpha iç tutarlılık katsayıları 0,50 ve 0,71 değerleri arasında hesaplanmış. İç geçerlik ile ilgili madde toplam, madde kalan ve madde ayırt ediciliği analizleri gerçekleştirilmiş ve TYDT sözel kısmın tüm puan türleri için $\mathrm{p}<.01$ düzeyinde anlamlı ilişkiler tespit edilmiştir.

\section{Veri Analizi}

Araştırmada elde edilen verilerin analizinde SPSS 13.0 paket programı kullanılmıştır. Normal dağılım sergileyen örneklemler üzerinde çalışırken parametrik istatistik tekniklerinin 
işe koşulması gerekmektedir (Büyüköztürk, 2007). Bu nedenle bağımlı değişkenden elde edilen tüm verilerin normallik varsayımını karşılayıp karşılamadığı Kolmogorov-Smirnov normallik testi ( $\mathrm{p}>.05)$ ile incelenmiş (Kalaycı, 2006), ve normallik varsayımını karşılamadığı görülmüştür. Halihazırda özel bir çalışma grubuyla gerçekleştirilmiş olan mevcut çalışmanın veri analizlerinde bu sebeple nonparametrik istatistik teknikleri kullanılmıştır. Araştırmada istatistiklerin sınanmasında anlamlılık düzeyi $\mathrm{p}<.05$ olarak kabul edilmiştir. Araştırmada başarı testi çoktan seçmeli form ve başarı testi uzun cevaplı sorular ve yaratıcı düşünme testi verilerinin analizi için ilişkisiz örneklemler testinde nonparametrik Mann-Whitney U testi uygulanırken, ilişkili örneklemler testinde noparametrik Wilcoxin-Z testi (Büyüköztürk, 2007; Kalayc1, 2006) işe koşulmuştur.

\section{Bulgular ve Yorumlar}

$\mathrm{Bu}$ bölümde, ölçme araçları ile toplanan veriler uygun istatistik teknikleri kullanılarak analiz edilmiş ve bulgular tablo haline getirilerek açıklanmıştır. Bu çalışmaya 48 öğrenci katılmıştır. Çalışmaya katılan öğrencilerin sınıf, zekâ ve cinsiyetlerine göre frekans dağılımları Tablo 1.'de verilmiştir.

Tablo 1. Öğrencilerin Gruplara, Zekâ Düzeylerine ve Cinsiyetlerine Göre Dağılımı

\begin{tabular}{llllll}
\hline & \multicolumn{3}{c}{ Kiz } & \multicolumn{3}{c}{ Erkek } & Toplam \\
\hline $\mathbf{N}=\mathbf{4 8}$ & $\mathbf{n}$ & $\mathbf{\%}$ & $\mathbf{n}$ & $\mathbf{\%}$ & $\mathbf{N}$ \\
Deney - Üstün & 4 & 30,8 & 9 & 69,2 & 13 \\
Deney- Normal & 6 & 50 & 6 & 50 & 12 \\
Kontrol - Üstün & 5 & 38,5 & 8 & 61,5 & 13 \\
Kontrol - Normal & 7 & 70 & 3 & 30 & 10 \\
\hline
\end{tabular}

Tablo 1'den anlaşılacağı üzere deney ve kontrol gruplarındaki toplam öğrenci sayısı 48'dir. Deney grubundaki 25 öğrencinin 10’u kız 15'i erkektir. Deney grubundaki 10 kız öğrencinin 4 tanesi üstün zihin düzeyindeyken 6 tanesi normal zihin düzeyindedir. Deney grubundaki 15 erkek öğrencininse 9 tanesi üstün zihin düzeyindeyken 6 tanesi normal zihin düzeyinde bulunmaktadır. Kontrol grubunda toplamda $12 \mathrm{k} 1 \mathrm{z}$ ve 11 erkek öğrenci bulunmaktadır. Kontrol grubundaki $12 \mathrm{kız} \mathrm{öğrencinin} 5$ tanesi üstün, kalan 7 tanesi ise normal zihin düzeyinde performans göstermektedir. kontrol grubunda bulunan erkek öğrencilerin 8 tanesi üstün 3 tanesi ise normal zihin düzeyinde bulunmaktadır.

Gruplar 5. sınıf ve 6. sınıf I. Dönem karne not ortalamaları ve Fen ve Teknoloji dersi not ortalamaları açısından Mann Whitney-U testi kullanılarak karşılaştırılmıştır ve gruplar arasında istatistiksel olarak anlamlı bir farka rastlanmamıştır. Bunlara ek olarak gruplar 
kullanılan ölçüm araçlarının ön test puanları açısından da karşılaştırılmış ve başarı ve yaratıcılık testi için gözlenen .92 ve $.90 p$ değerleri istatistiksel olarak anlamlı bulunmamıştır (p>.05). Bu da grupların denel işlem öncesinde incelenen değişkenler açısından birbirlerine denk olduğunu göstermektedir.

Tablo 2. Grupların Başarı Testi Toplam Sontest Puanları İçin Yapılan Mann-Whitney U Testi Sonuçları

\begin{tabular}{llllllll}
\hline $\begin{array}{l}\text { Sontest- } \\
\text { Toplam }\end{array}$ & $\begin{array}{l}\text { Soru } \\
\text { sayısı }\end{array}$ & $N$ & S. $\boldsymbol{T}$. & S.O. & $\boldsymbol{U}$ & $\boldsymbol{z}$ & $\mathbf{p}$ \\
\hline Kontrol & 45 & 23 & 13,48 & 310,00 & & & \\
Deney & 45 & 25 & 34,64 & 866,00 & 34,000 & $-5,234$ &, 000 \\
\hline
\end{tabular}

Tablo 2'de görüldüğü gibi, grupların başarı testi toplam sontest puan ortalamaları arasındaki farkın belirlenmesine yönelik Mann-Whitney U testi yapılmış ve gözlenen 34,000 "U" değeri .00 manidarlık düzeyinde anlamlı bulunmuştur. Bu verilere dayanarak fen ve teknoloji dersinin öğretiminde probleme dayalı öğrenme ile yapılan öğretimin toplam davranışları (bilgi, kavrama, uygulama, analiz, sentez ve değerlendirme) kazandırmada kontrol grubunda yapılan öğretime göre daha etkili olduğu ve başarıyı arttırdığı söylenebilir.

Tablo 3. Grupların Başarı Testi Toplam Erişi Puanları İçin Yapılan Mann-Whitney U Testi Sonuçları

\begin{tabular}{llllllll}
\hline Erişi- Toplam & $\begin{array}{l}\text { Soru } \\
\text { sayısı }\end{array}$ & $\boldsymbol{N}$ & $\boldsymbol{S . T .}$ & $\boldsymbol{S} . \boldsymbol{O}$. & $\boldsymbol{U}$ & $\boldsymbol{z}$ & $\mathrm{p}$ \\
\hline Kontrol & 45 & 23 & 12,00 & 276,00 & & & \\
Deney & 45 & 25 & 36,00 & 900,00 & 0,000 & $-5,936$ &, 000 \\
\hline
\end{tabular}

Tablo 3'te görüldüğü gibi, grupların başarı testi toplam erişi yani son test ve ön test puan ortalamaları arasındaki farkın belirlenmesine yönelik Mann-Whitney U testi yapılmış ve gözlenen 0,000 "U” değeri .000 manidarlık düzeyinde anlamlı bulunmuştur. Bu sonuç PDÖ temelli fen ve teknoloji öğretiminin deney grubunun başarısını kontrol grubuna göre anlamlı şekilde arttırdığını ortaya koymaktadır.

Tablo 4. Kontrol Grubunun Başarı Testi Toplam Öntest-Sontest Puanları İçin Yapılan Wilcoxon Testi Sonuçları

\begin{tabular}{|c|c|c|c|c|c|c|}
\hline Puan & Siralar & $\mathbf{N}$ & S.O. & & $\mathbf{z}$ & p \\
\hline \multirow{2}{*}{$\begin{array}{l}\text { Kontrol Grubu } \\
\text { Öntest - Sontest } \\
\text { (Toplam Düzeyi) }\end{array}$} & Negatif & 1 & 2,00 & 2,00 & \multirow[b]{2}{*}{$-4,140$} & \multirow[b]{2}{*}{, 000} \\
\hline & $\begin{array}{l}\text { Siralar } \\
\text { Pozitif }\end{array}$ & 22 & 12,45 & 274,00 & & \\
\hline
\end{tabular}




$\begin{array}{ll}\text { Eşit } & 0 \\ \text { Total } & 23\end{array}$

Tablo 4'te görüldüğü gibi, kontrol grubunun başarı testi toplam öntest-sontest puan ortalamaları arasındaki farkın belirlenmesine yönelik Wilcoxon testi yapılmış ve gözlenen 4,140 “Z” değeri ,000 düzeyinde anlamlı bulunmuştur. Bu verilere dayanarak kontrol grubunda verilen öğretimin kontrol grubu öğrencilerinin toplam başarılarını arttırdığı söylenebilir. Kontrol grubundaki öğrencilerin başarı testindeki performanslarının artması konuyu işledikten sonra MEB'in temel kazanımlarını edindiklerini göstermektedir ve beklenen bir durumdur.

Tablo 5. Deney Grubunun Başarı Testi Toplam Öntest-Sontest Puanları İçin Yapılan Wilcoxon Testi Sonuçları

\begin{tabular}{lllllll}
\hline Puan & Sıralar & N & S.O. & & $\mathbf{z}$ & $\mathbf{p}$ \\
\hline & Negatif & 0 &, 00 &, 00 & & \\
Deney Grubu & Siralar & & & & & \\
Öntest - Sontest & Pozitif & 25 & 13,00 & 325,00 & $-4,373$ &, 000 \\
(Toplam Düzeyi) & Siralar & & & & & \\
& Eşit & 0 & & & & \\
& Total & 25 & & & & \\
\hline
\end{tabular}

Tablo 5'te görüldüğü gibi, deney grubunun başarı testi toplam öntest-sontest puan ortalamaları arasındaki farkın belirlenmesine yönelik Wilcoxon testi yapılmış ve gözlenen 4,373 “Z” değeri ,000 düzeyinde anlamlı bulunmuştur. Bu verilere dayanarak deney grubunda yapılan probleme dayalı öğretimin deney grubu öğrencilerinin toplam başarılarını arttırdığı söylenebilir.

Tablo 6.Üstün Zeka Düzeyindeki Öğrencilerin Başarı Testi Toplam Sontest Puanları İçin Yapılan Mann-Whitney U Testi Sonuçları

\begin{tabular}{lccccccc}
\hline $\begin{array}{l}\text { Sontest- } \\
\text { Toplam }\end{array}$ & $\begin{array}{c}\text { Soru } \\
\text { sayısı }\end{array}$ & $\boldsymbol{N}$ & $\boldsymbol{S . T .}$ & $\boldsymbol{S . O}$. & $\boldsymbol{U}$ & $\boldsymbol{Z}$ & $\boldsymbol{p}$ \\
\hline Kontrol-Üstün & 45 & 13 & 7,31 & 95,00 & & & \\
Deney-Üstün & 45 & 13 & 19,69 & 256,00 & 4,000 & $-4,132$ &, 000 \\
\hline
\end{tabular}

Tablo 6'da görüldügü gibi, grupların başarı testi toplam sontest puan ortalamaları arasındaki farkın belirlenmesine yönelik Mann-Whitney U testi yapılmış ve gözlenen 4,000 "U” değeri .01 manidarlık düzeyinde anlamlı bulunmuştur. Bu verilere dayanarak fen ve teknoloji dersinin öğretiminde probleme dayalı öğrenme ile yapılan öğretimin toplam 
davranışları kazandırmada geleneksel öğretime göre daha etkili olduğu ve başarıyı arttırdığı söylenebilir.

Tablo 7. Kontrol Grubunda Bulunan Üstün Zeka Düzeyindeki Öğrencilerin Başarı Testi ÖntestSontest Puanları İçin Yapılan Wilcoxon Testi Sonuçları

\begin{tabular}{lllllll}
\hline Puan & Siralar & N & S.O. & z & p \\
\hline Kontrol Grubu & Negatif Sıralar & 1 & 2,00 & 2,00 & & \\
Öntest - Sontest & Pozitif Sıralar & 12 & 7,42 & 89,00 & & \\
(Toplam) & Eşit & 0 & & & $-3,044$ &, 002 \\
& Total & 13 & & & & \\
\hline
\end{tabular}

Tablo 7'de görüldüğü gibi, kontrol grubunun başarı testi toplam öntest-sontest puan ortalamaları arasındaki farkın belirlenmesine yönelik Wilcoxon testi yapılmış ve gözlenen 3,044 "Z" değeri ,01 düzeyinde anlamlı bulunmuştur. Bu verilere dayanarak kontrol grubunda verilen geleneksel öğretimin kontrol gurubu öğrencilerinin toplam başarılarını arttırdığı söylenebilir.

Tablo 8. Deney Grubunda Bulunan Üstün Zeka Düzeyindeki Öğrencilerin Başarı Testi ÖntestSontest Puanları İçin Yapılan Wilcoxon Testi Sonuçları

\begin{tabular}{lllllll}
\hline Puan & Sıralar & N & S.O. & & $\mathbf{z}$ & $\mathbf{p}$ \\
\hline & Negatif & 0 &, 00 &, 00 & & \\
Deney Grubu & Siralar & & & & & \\
Öntest - Sontest & Pozitif Sıralar & 13 & 7,00 & 91,00 & $-3,188$ &, 001 \\
(Toplam) & Eşit & 0 & & & & \\
& Total & 13 & & & & \\
\end{tabular}

Tablo 8'de görüldüğ̈̈ gibi, deney grubunun başarı testi toplam öntest-sontest puan ortalamaları arasındaki farkın belirlenmesine yönelik Wilcoxon testi yapılmış ve gözlenen 3,188 "Z" değeri ,01 düzeyinde anlamlı bulunmuştur. Bu verilere dayanarak deney grubunda yapılan probleme dayalı öğretimin deney grubunda bulunan üstün zekalı öğrencilerinin toplam başarılarını arttırdığı söylenebilir.

Tablo 9. Normal Zeka Düzeyindeki Öğrencilerin Başarı Testi Toplam Sontest Puanları İçin Yapılan Mann-Whitney U Testi Sonuçları

\begin{tabular}{llllllll}
\hline Sontest- & Soru & N & S.T. & S.O. & $U$ & $z$ & $p$ \\
Toplam & sayıs & & & & & \\
\hline
\end{tabular}




\begin{tabular}{|c|c|c|c|c|c|c|c|}
\hline Kontrol- & 45 & 10 & 6,15 & 61,50 & & & \\
\hline Normal & & & & & 6,500 & $-3,531$ &, 000 \\
\hline Deney-Normal & 45 & 10 & 6,15 & 61,50 & & & \\
\hline
\end{tabular}

Tablo 9'da görüldüğü gibi, grupların başarı testi toplam öntest puan ortalamaları arasındaki farkın belirlenmesine yönelik Mann-Whitney U testi yapılmış ve gözlenen 6,500 "U” değeri .01 manidarlık düzeyinde anlamlı bulunmuştur. Bu verilere dayanarak fen ve teknoloji dersinin öğretiminde probleme dayalı öğrenme ile yapılan öğretimin toplam davranışları kazandırmada geleneksel öğretime göre daha etkili olduğu ve başarıyı arttırdığı söylenebilir.

Tablo 10. Normal Zeka Düzeyindeki Öğrencilerin Başarı Testi Toplam Erişi Puanları İçin Yapılan Mann-Whitney U Testi Sonuçları

\begin{tabular}{lccccccc}
\hline Erişi- Toplam & $\begin{array}{c}\text { Soru } \\
\text { sayısı }\end{array}$ & $\boldsymbol{N}$ & S.T. & S.O. & $\boldsymbol{U}$ & $\boldsymbol{z}$ & $\boldsymbol{p}$ \\
\hline Kontrol- & 45 & 10 & 5,50 & 55,00 & & & \\
Normal & & & & &, 000 & $-3,960$ &, 000 \\
Deney-Normal & 45 & 12 & 16,50 & 198,00 & & & \\
\hline
\end{tabular}

Tablo 10'da görüldüğü gibi, grupların başarı testi toplam erişi puan ortalamaları arasındaki farkın belirlenmesine yönelik Mann-Whitney U testi yapılmış ve gözlenen ,000 "U” değeri .01 manidarlık düzeyinde anlamlı bulunmuştur. Bu verilere dayanarak fen ve teknoloji dersinin öğretiminde probleme dayalı öğrenme ile yapılan öğretimin toplam davranışları kazandırmada geleneksel öğretime göre daha etkili olduğu ve başarıyı arttırdığı söylenebilir.

Tablo 11. Kontrol Grubunda Bulunan Normal Zeka Düzeyindeki Öğrencilerin Başarı Testi ÖntestSontest Puanları İçin Yapılan Wilcoxon Testi Sonuçları

\begin{tabular}{lllllll}
\hline Puan & Suralar & N & S.O. & z & p \\
\hline & Negatif & 0 &, 00 &, 00 & & \\
Kontrol Grubu & Siralar & & & & & \\
Öntest - Sontest & Pozitif Siralar & 10 & 5,50 & 55,00 & $-2,807$ &, 005 \\
(Toplam) & Eşit & 0 & & & & \\
& Total & 10 & & & & \\
\hline
\end{tabular}


Tablo 11'de görüldüğü gibi, kontrol grubunun başarı testi toplam öntest-sontest puan ortalamaları arasındaki farkın belirlenmesine yönelik Wilcoxon testi yapılmış ve gözlenen 2,807 “Z” değeri ,01 düzeyinde anlamlı bulunmuştur. Bu verilere dayanarak kontrol grubunda verilen geleneksel öğretimin kontrol grubunda bulunan normal zeka düzeyindeki öğrencilerinin toplam başarılarını arttırdığı söylenebilir.

Tablo 12. Deney Grubunda Bulunan Normal Zeka Düzeyindeki Öğrencilerin Başarı Testi ÖntestSontest Puanları İçin Yapılan Wilcoxon Testi Sonuçları

\begin{tabular}{lllllll}
\hline Puan & Sıralar & $\mathbf{N}$ & S.O. & $\mathbf{z}$ & $\mathbf{p}$ \\
\hline & Negatif & 0 &, 00 &, 00 & & \\
Deney Grubu & Siralar & & & & & \\
Öntest - Sontest & Pozitif Siralar & 12 & 6,50 & 78,00 & $-3,061$ &, 002 \\
(Toplam) & Eşit & 0 & & & & \\
& Total & 12 & & & & \\
& & & & & & \\
\hline
\end{tabular}

Tablo 12'de görüldüğü gibi, deney grubunun başarı testi toplam öntest-sontest puan ortalamaları arasındaki farkın belirlenmesine yönelik Wilcoxon testi yapılmış ve gözlenen 3,061 "Z" değeri ,001 düzeyinde anlamlı bulunmuştur. Bu verilere dayanarak deney grubunda yapılan probleme dayalı öğretimin deney grubu öğrencilerinin toplam başarılarını arttırdığı söylenebilir.

Tablo 13'te görüldüğü gibi kontrol grubunun Torrance Yaratıcı Düşünme Testi A ve B formu sözel akıcılık, esneklik, özgünlük ve toplam puanlarına ait değerler sırasıyla 27,28; 27,$10 ; 26,86 ; 26,62,26,30 ; 26,28$ ve 26,$88 ; 26,82$ olarak bulunmuştur. Buna ek olarak, deney grubunun Torrance Yaratıcı Düşünme Testi A ve B formu sözel akıcılık, esneklik, özgünlük ve toplam puanlarına ait değerler sırasıyla 21,$48 ; 21,67 ; 21,93 ; 22,20,22,54 ; 22,57$ ve 21,91; 21,98 olarak bulunmuştur.

Deney ve kontrol grubunun yaratıcı düşünme düzeyi sontestlerinin karşılaştırılması için yapılan Mann Whitney-U testi sonuçlarına göre B formu akıcılık, esneklik, özgünlük ve toplam puanlarında sırasıyla 222,500, 234,500, 243,000 ve 229,00 “U” değerleri gözlenmiştir. $\mathrm{Bu}$ değerler .05 düzeyinde istatiksel olarak anlamlı bulunmamıştır. Bu verilere dayanarak fen ve teknoloji dersi öğretiminde kullanılan probleme dayalı öğrenmenin öğrencilerin yaratıcı düşünme düzeylerini kontrol grubunda yapılan öğretime göre anlamlı şekilde arttırmadığ 1 söylenebilir. 
Tablo 13. Grupların Torrance Yaratıcı Düşünme Testi A ve B Formları Sözel Kısımları İçin Yapılan Mann Whitney-U Testi Sonuçları

\begin{tabular}{|c|c|c|c|c|c|c|c|}
\hline $\begin{array}{l}\text { Sözel } \\
\text { Yaratıcılık }\end{array}$ & Şube & $\mathbf{N}$ & S.T & S.O & $\mathbf{U}$ & $\mathbf{z}$ & p \\
\hline \multirow{2}{*}{$\begin{array}{l}\text { A Formu } \\
\text { Akicilık }\end{array}$} & Kontrol & 23 & 21,48 & 494,00 & \multirow[t]{2}{*}{218,000} & \multirow{2}{*}{$-1,435$} & \multirow{2}{*}{, 151} \\
\hline & Deney & 25 & 27,28 & 682,00 & & & \\
\hline \multirow{2}{*}{$\begin{array}{l}\text { A Formu } \\
\text { Esneklik }\end{array}$} & Kontrol & 23 & 21,93 & 504,50 & \multirow{2}{*}{228,500} & \multirow{2}{*}{$-1,221$} & \multirow{2}{*}{, 222} \\
\hline & Deney & 25 & 26,86 & 671,50 & & & \\
\hline \multirow{2}{*}{$\begin{array}{l}\text { A Formu } \\
\text { Orjinallik }\end{array}$} & Kontrol & 23 & 22,54 & 518,50 & \multirow{2}{*}{242,500} & \multirow{2}{*}{,- 930} & \multirow{2}{*}{,353 } \\
\hline & Deney & 25 & 26,30 & 657,50 & & & \\
\hline \multirow{2}{*}{$\begin{array}{l}\text { A Formu } \\
\text { Toplam }\end{array}$} & Kontrol & 23 & 21,91 & 504,00 & \multirow{2}{*}{228,000} & \multirow{2}{*}{$-1,228$} & \multirow{2}{*}{,219 } \\
\hline & Deney & 25 & 26,88 & 672,00 & & & \\
\hline \multirow{2}{*}{$\begin{array}{l}\text { B Formu } \\
\text { Akıcılık }\end{array}$} & Kontrol & 23 & 21,67 & 498,50 & \multirow{2}{*}{222,500} & \multirow{2}{*}{$-1,342$} & \multirow{2}{*}{, 180} \\
\hline & Deney & 25 & 27,10 & 677,50 & & & \\
\hline \multirow{2}{*}{$\begin{array}{l}\text { B Formu } \\
\text { Esneklik }\end{array}$} & Kontrol & 23 & 22,20 & 510,50 & \multirow{2}{*}{234,500} & \multirow{2}{*}{$-1,097$} & \multirow{2}{*}{,273 } \\
\hline & Deney & 25 & 26,62 & 665,50 & & & \\
\hline \multirow{2}{*}{$\begin{array}{l}\text { B Formu } \\
\text { Orjinallik }\end{array}$} & Kontrol & 23 & 22,57 & 519,00 & \multirow{2}{*}{243,000} & \multirow{2}{*}{,- 919} & \multirow{2}{*}{,358 } \\
\hline & Deney & 25 & 26,28 & 657,00 & & & \\
\hline \multirow{2}{*}{$\begin{array}{l}\text { B Formu } \\
\text { Toplam }\end{array}$} & Kontrol & 23 & 21,98 & 505,50 & \multirow{2}{*}{229,500} & \multirow{2}{*}{$-1,197$} & \multirow{2}{*}{,231 } \\
\hline & Deney & 25 & 26,82 & 670,50 & & & \\
\hline
\end{tabular}

Tablo 14. Grupların Torrance Yaratıcı Düşünme Testi A ve B Formları Sözel Kısımlar Erişi Puanları İçin Yapılan Mann Whitney-U Testi Sonuçları

\begin{tabular}{lllllll}
\hline Erişi & $\boldsymbol{N}$ & $\boldsymbol{S . T .}$ & S.O. & $\boldsymbol{U}$ & $\boldsymbol{z}$ & $\mathbf{p}$ \\
\hline Kontrol & 23 & 24,37 & 560,50 & & & \\
Deney & 25 & 24,62 & 615,50 & & &, 951 \\
\hline
\end{tabular}

Tablo 14'te görüldüğü gibi, grupların Torrance Yaratıcı Düşünme Testi puan ortalamaları arasındaki farkın belirlenmesine yönelik Mann-Whitney U testi yapılmış ve gözlenen 284,500 "U” değeri .05 manidarlık düzeyinde anlamlı bulunmamıştır. Bu verilere dayanarak fen ve teknoloji dersinin öğretiminde probleme dayalı öğrenme ile yapılan öğretimin yaratıcı düşünme düzeyini kontrol grubunda yapılan öğretime göre grup ilerleme puanları açısından incelediğinde arttırmadığı söylenebilir. 
Tablo 15. Kontrol Grubu Torrance Yaratıcı Düşünme Testi A ve B Formları Sözel Kısımlar ÖntestSontest Puanları İçin Yapılan Wilcoxon Testi Sonuçları

\begin{tabular}{lllllll}
\hline Puan & Sıralar & N & S.O. & z & p \\
\hline & Negatif & 6 & 8,75 & 52,50 & & \\
Kontrol Grubu & Siralar & & & & & \\
Öntest - Sontest & Pozitif & 16 & 12,53 & 200,50 & $-2,403$ &, 016 \\
& Siralar & & & & & \\
& Eşit & 1 & & & & \\
& Total & 23 & & & & \\
\hline
\end{tabular}

Tablo 15.'te görüldüğü gibi, kontrol grubu öğrencilerinin Torrance Yaratıcı Düşünme Testi öntest-sontest puan ortalamaları arasındaki farkın belirlenmesine yönelik Wilcoxon testi yapılmış ve gözlenen $-2,403$ “ $Z$ ” değeri .05 manidarlık düzeyinde anlamlı bulunmuştur. $\mathrm{Bu}$ sonuç kontrol grubundaki öğrencilerin yaratıcılık skorlarında ön-son testler bağlamında bir ilerleme kaydettiklerini göstermektedir.

Tablo 16. Deney Grubu Torrance Yaratıcı Düşünme Testi A ve B Formları Sözel Kısımlar ÖntestSontest Puanları İçin Yapılan Wilcoxon Testi Sonuçları

\begin{tabular}{lllllll}
\hline Puan & Sıralar & N & S.O. & z & p \\
\hline & Negatif & 2 & 2,25 & 4,50 & & \\
Deney Grubu & Siralar & & & & & \\
Öntest - Sontest & Pozitif & 23 & 13,93 & 320,50 & $-4,252$ &, 000 \\
& Siralar & & & & & \\
& Eşit & 0 & & & & \\
& Total & 25 & & & & \\
\hline
\end{tabular}

Tablo 16.'da görüldüğü gibi, deney grubu öğrencilerin Torrance Yaratıcı Düşünme Testi öntest-sontest puan ortalamaları arasındaki farkın belirlenmesine yönelik Wilcoxon testi yapılmış ve gözlenen -4,252 “Z” değeri .00 düzeyinde anlamlı bulunmuştur. Bu verilere dayanarak fen ve teknoloji dersinin öğretiminde probleme dayalı öğrenme ile yapılan öğretimin öğrencilerin yaratıcı düşünme düzeylerini arttırdığı söylenebilir.

Kontrol ve deney grubunda bulunan üstün öğrencilerin Torrance yaratıcı düşünme testi skorları Mann-Whitney U testi yapılarak karşılaştırılmıştır. Kontrol grubunun Torrance Yaratıcı Düşünme Testi A ve B formu sözel akıcılık, esneklik, özgünlük ve toplam puanlarına ait değerler sırasıyla 27,$28 ; 27,10 ; 26,86 ; 26,62 ; 26,30 ; 26,28$ ve 26,$88 ; 26,82$ olarak bulunmuştur. Buna ek olarak, deney grubunun Torrance Yaratıcı Düşünme Testi A ve B formu sözel akıcılık, esneklik, özgünlük ve toplam puanlarına ait değerler sırasıyla 21,48; 21,$67 ; 21,93 ; 22,20 ; 22,54 ; 22,57$ ve 21,$91 ; 21,98$ olarak bulunmuştur. 
Deney ve kontrol grubunda bulunan üstün zeka düzeyindeki öğrencilerin yaratıcı düşünme düzeyi son testlerinin karşılaştırılması için yapılan Mann Whitney-U testi sonuçlarına göre B formu akıcılık, esneklik, özgünlük ve toplam puanlarında sırasıyla 222,500, 234,500, 243,000 ve 229,00 "U” değerleri gözlenmiştir. Bu değerler .05 düzeyinde istatiksel olarak anlamlı bulunmamıştır. $\mathrm{Bu}$ verilere dayanarak fen ve teknoloji dersi öğretiminde kullanılan probleme dayalı öğrenmenin öğrencilerin yaratıcı düşünme düzeylerini geleneksel öğretime göre anlamlı şekilde arttırmadığı söylenebilir.

Kontrol ve deney grubunda bulunan normal öğrencilerin Torrance yaratıcı düşünme testi skorları Mann-Whitney U testi yapılarak karşılaştırılmıştır. Kontrol grubunun Torrance Yaratıcı Düşünme Testi A ve B formu sözel akıcılık, esneklik, özgünlük ve toplam puanlarına ait değerler sırasıyla 27,28;27,10;26,86;26,62;26,30;26,28 ve 26,88;26,82 olarak bulunmuştur. Buna ek olarak, deney grubunun Torrance Yaratıcı Düşünme Testi A ve B formu sözel akıcılık, esneklik, özgünlük ve toplam puanlarına ait değerler sırasıyla 21,48; 21,$67 ; 21,93 ; 22,20 ; 22,54 ; 22,57$ ve 21,$91 ; 21,98$ olarak bulunmuştur.

Deney ve kontrol grubunda bulunan normal zeka düzeyindeki öğrencilerin yaratıcı düşünme düzeyi son testlerinin karşılaştırılması için yapılan Mann Whitney-U testi sonuçlarına göre B formu akıcılık, esneklik, özgünlük ve toplam puanlarında sırasıyla 222,500, 234,500, 243,000 ve 229,00 "U” değerleri gözlenmiştir. Bu değerler .05 düzeyinde istatiksel olarak anlamlı bulunmamıştır. $\mathrm{Bu}$ verilere dayanarak fen ve teknoloji dersi öğretiminde kullanılan probleme dayalı öğrenmenin öğrencilerin yaratıcı düşünme düzeylerini geleneksel öğretime göre anlamlı şekilde arttırmadığı söylenebilir.

Kontrol ve deney grubunda bulunan öğrencilerin Torrance Yaratıcı Düşünme Testi skorları daha ayrıntılı şekilde incelendiğinde deney grubunda bulunan üstün zeka düzeyindeki öğrencilerin TYDT öntest-sontest puan ortalamaları arasındaki farkın belirlenmesine yönelik Wilcoxon testi yapılmış ve gözlenen -3,041 “Z” değeri .00 manidarlık düzeyinde anlamlı bulunmuştur. Kontrol grubunda bulunan üstün zeka düzeyindeki öğrencilerin TYDT öntestsontest puan ortalamaları arasındaki farkın belirlenmesine yönelik yapılan Wilcoxon testi sonucunda gözlenen -2,271 "Z" değeri ise .05 manidarlık düzeyinde anlamlı bulunmuştur. Buna karşılık kontrol grubunda bulunan normal zeka düzeyindeki öğrencilerin TYDT öntestsontest puan ortalamaları arasındaki farkın belirlenmesine yönelik yapılan Wilcoxon testi sonucunda gözlenen -,178 “Z” değeri .05 manidarlık düzeyinde anlamlı bulunmamıştır. Fakat deney grubunda bulunan normal zeka düzeyindeki öğrencilerin TYDT öntest-sontest puan ortalamaları arasındaki farkın belirlenmesine yönelik yapılan Wilcoxon testi sonucunda 
gözlenen -2,982 "Z" değeri .01 manidarlık düzeyinde anlamlı bulunmuştur. $\mathrm{Bu}$ verilere dayanarak fen ve teknoloji dersinin öğretiminde probleme dayalı öğrenme ile yapılan öğretimin yaratıcı düşünme düzeyini geleneksel öğretime göre grup ilerleme puanları açısından incelendiğinde arttırdığı ve etkili olduğu söylenebilir.

\section{Sonuç ve Tartışma}

Mevcut araştırmada elde edilen bulgular deney ve kontrol gruplarının başarı testi toplam puanlarının sontest ve erişi puanları arasında anlamlı bir farkın bulunduğunu göstermektedir. Bu bulgular kontrol grubu ve deney grubu arasında başarı testi toplam puanlarının erişileri bakımından deney grubu lehine beklenen öngörüyü destekler niteliktedir. Araştırma esnasında hedef ve davranışlar, MEB tarafından oluşturulan ilköğretim programındaki hedef ve davranışlar ile üstün zekalı ve yetenekli öğrencilerin de öğrenme ihtiyaçlarını karşılayabilecek şekilde probleme dayalı öğrenmenin özellikleri dikkate alınarak oluşturulmuştur. Günlük ders planları hazırlanılırken genel plan yapısı olarak Sönmez (2007) tarafından önerilen plan yapısı tercih edilmiştir. Derslerin işleniş sürecinde yapılandırmacı felsefe benimsenmiş ve bunun bir gereği olarak öğrencilerin bilgiye kendilerinin ulaşması desteklenmiştir. Öğretmen sınıfta bilgiyi hazır olarak veren kişi değil sadece öğrenme yaşantılarına rehberlik eden kişi olarak yer almıştır. Kullanılan probleme dayalı öğrenme yöntemi sayesinde sınıfta bulunan farklı profillere sahip öğrencilerin öğrenme ihtiyaçları karşılanmaya çalışılmıştır. Şöyle ki, ünite boyunca çözümü aranan problem senaryosu ile ilgili her öğrenci kendi ilgi, yetenek ve becerileri doğrultusunda ve bu yeteneklerin imkan verdiği derinlikte ve kapsamda araştırmalar yapmışlardır. Oluşturulan gruplar sayesinde farklı profillerdeki öğrenciler öğrenme deneyimlerini birbiriyle paylaşma ve birlikte bir ürün ortaya koyma firsatını yakalamışlardır.

Sonuç olarak, İlköğretim 6. sınıf Fen ve Teknoloji dersi "Yaşamımızdaki Elektrik" ünitesinde Probleme Dayalı Öğrenme ile öğretim yapılan grubun başarı testi toplam puanlarının erişisi ile kontrol grubunun başarı testi toplam puanlarının erişi puanları arasında deney grubu lehine anlamlı bir fark çıkmıştır. Buradan hareketle, probleme dayalı öğrenme ile öğretim yapılan deney grubunun kontrol grubundan daha başarılı olduğu söylenebilir.

Şenocak (2005), probleme dayalı öğrenme yaklaşımından "Maddenin Gaz Hali” ünitesinde yararlanmıştır. Araştırmacı; elde ettiği bulgulardan öğrenme sürecinde yararlandığg probleme dayalı öğrenme yaklaşımının geleneksel öğretim yaklaşımına oranla daha etkili olduğunu saptamıştır. 
Yaman (2003) tarafından yapılan çalışmada PDÖ yaklaşımının lisans düzeyindeki öğrencilerin akademik başarılarına olumlu etkileri olduğu ortaya konulmuştur. Sungur (2004) araştırmasında, Lise Biyoloji dersinde uygulanan probleme dayalı öğrenmenin öğrencilerin akademik başarısını arttırdığını ifade etmiştir. Parim (2001) çalışmasında, ilköğretim fen bilgisi dersinde probleme dayalı öğrenme yaklaşımının kullanılmasının öğrencilerin akademik başarılarını anlamlı derecede artırdığını tespit etmiştir. Ayrıca Deveci (2002) gerçekleştirdiği çalışmada; ilköğretim sosyal bilgiler dersinde probleme dayalı öğrenme uygulamasının, öğrencilerin akademik başarılarını deney grubu lehine anlamlı düzeyde farklılaştırdığını belirlemiştir. Mckinnon 1999 yılında yaptı̆̆ı araştırmada PDÖ’nün öğrenci başarısını arttırdığı bulgusuna erişmiştir (aktaran Yaman, 2003).

Bunlara ek olarak Tavukçu (2006), probleme dayalı öğrenmenin öğrenme ürünlerine etkisini incelediği çalışmasında probleme dayalı öğrenmenin öğrencilerin akademik başarılarını, fen bilimlerine yönelik tutumlarını ve yaratıcı düşünme düzeylerini arttırdığı sonucuna erişmiştir. Mevcut araştırmanın bulguları literatürdeki farklı çalışmalarla örtüşmekte ve probleme dayalı öğrenmenin öğrenci başarısını arttırdığı bulgusunu desteklemektedir.

$\mathrm{Bu}$ araştırmada elde edilen bulgular grupların Torrance Yaratıcı Düşünme Testi son test puan ortalamaları açısından farklılaşmadığını göstermektedir. Grupların Torrance Yaratıcı Düşünme Testi erişi puan ortalamalarının da farklılaşmadığı gözlenmiştir. Deney ve kontrol grubunda bulunan üstün zekalı öğrencilerin TYDT son test ve erişi puanları arasında anlamlı bir farka rastlanmamıştır. Fakat kontrol grubunda bulunan üstün öğrenciler TYDT ön-son testleri arasında .05 manidarlık düzeyinde ilerleme sergilerken, deney grubunda bulunan üstün öğrenciler ,00 düzeyinde ilerleme sergilemişlerdir. Bu da deney grubundaki öğrencilerin yaratıcılık puanlarının kontrol grubuna göre daha fazla arttığı fakat bu artışın anlamlı farklılık yaratacak düzeyde gerçekleşmediği şeklinde yorumlanabilir. Aksoy (2005), Koray (2003), Onargan ve arkadaşları (2004), Tavukçu (2006), Yaman (2003), tarafindan yapılan çalışmalarda probleme dayalı öğrenme uygulamalarının öğrencilerin yaratıcı düşünme düzeylerini olumlu yönde etkilediği sonucuna ulaşılmıştır. Bu araştırmaların bulguları mevcut çalışmanın bulgularıyla (normal profilde yer alan öğrenciler adına erişilen bulgular dışında) örtüşmemektedirler.

Deney ve kontrol grubunda bulunan farklı profillerdeki öğrencilerin TYDT sonuçları daha ayrıntılı bir biçimde incelendiğinde deney grubunun ön-son testte .00 manidarlık düzeyinde ilerleme sergilerken kontrol grubunun .05 düzeyinde ilerleme kaydettiği 
gözlenmiştir. Ayrıca deney grubundaki öğrenciler (üstün ve normal) öğretim süreci içerisinde Torrance Yaratıcı Düşünme Testi puanlarında .00 anlamlılık ortaya koyacak bir ilerleme sergilerken, kontrol gurubunun üstün zeka düzeyine sahip öğrencileri .05 düzeyinde ilerleme sergilemiş, kontrol grubunda bulunan normal zeka düzeyine sahip öğrenciler ise istatistiksel olarak anlamlı bir ilerleme sergilememişlerdir. $\mathrm{Bu}$ durumun sebepleri arasında deney ve kontrol gruplarına dahil edilmiş olan öğrencilerin proje okulunda yürütülen projeye dahil olan öğrenciler olmaları gösterilebilir. Zira bu öğrenciler 6 yıldır yürütülen projenin içerisinde yer almaktadırlar ve projenin kapsamı gereği 6 yıldır her hafta 1 ders saati süreyle yaratıcılık eğitimi almaktadırlar. 6 yıl boyunca deney ve kontrol gruplarında bulunan öğrencilerin tümüyle birlikte sürdürülmüş olan yaratıcılık eğitiminin gruplar arasında yaratıcı düşünme düzeyi açısından var olan farkı ortadan kaldırmış olması muhtemeldir. Deney ve kontrol grupları arasında TYDT puanları arasında anlamlı fark bulunamamasının bir başka sebebi olarak çalışmanın süresi gösterilebilir, yaratıcılık karmaşık bir kavram ve düşünme süreci olması hasebiyle geliştirilmesi için de uzun süreli eğitime ihtiyaç duyulacağı düşünülebilir. Bunların yanı sıra yapılan çalışma fen bilimlerine özgüdür fakat yaratıcılık ölçümü olarak genel yaratıcılığı ölçtüğü düşünülen TYDT kullanılmıştır, uygulanan farklılaştırılmış programın alana özgü yaratıcılığı geliştirme konusunda daha başarılı olacağı varsayılabilir.

\section{Öneriler}

Araştırmanın bulguları göz önüne alınarak aşağıdaki önerilerde bulunulabilir.

1. Geliştirilen eğitim programı İstanbul ili ile sınırlı olduğundan bu çalışmanın Türkiye'nin başka bölgelerinde de uygulanmasına ve farklı çalışma grupları üzerinde test edilmesine ihtiyaç duyulmaktadır.

2. Geliştirilen eğitim programı sadece bir üniteyi kapsadığı için üstün zekalı ve yetenekli öğrencilerin fen eğitimindeki farklılaştırma ihtiyaçlarını karşılamada yetersizdir. $\mathrm{Bu}$ sebepten ülkemizde fen programlarının bu çok yetenekli öğrencilerimizin ihtiyaçlarını karşılayacak şekilde planlanması yararlı olacaktır.

3. Öğretmenlerin eğitim alanındaki gelişmelerden ve üstün zekalı ve yetenekli öğrencilerde kullanılacak eğitim-öğretim yöntemlerinden haberdar olması ve etkili biçimde uygulayabilmesi adına mesleki bilgi ve becerilerini geliştirecek hizmet içi eğitim kursları düzenlenmelidir. 
4. Üstün zekalı ve yetenekli öğrencilerde etkili olduğu düşünülen farklı öğretim yöntemleri ve farklı konu alanları üzerinde çalışmalar yapılarak araştırmalar zenginleştirilmelidir.

5. Bu konuda daha kesin genellemelere varabilmek için daha geniş örneklemler üzerinde çalışılmalıdır.

\section{KAYNAKÇA}

Aksoy, G. (2005). "Fen Eğitiminde Yaratıcı Düşünme Temelli Bilimsel Yöntem Sürecinin Öğrenme Ürünlerine Etkisi”, Yayınlanmamış Yüksek Lisans Tezi, Zonguldak Karaelmas Üniversitesi.

Aslan, A.E. (2001). Torrance Yaratıcı Düşünce Testi’nin Türkçe Versiyonu. Marmara Üniversitesi Atatürk Eğitim Fakültesi Eğitim Bilimleri Dergisi. 14, 19-40.

Büyüköztürk, Ş. (2007). Deneysel desenler. (2. Bask1). Ankara: PegemA Yayıncılık.

Chin, C \& Chia, L. (2004). Problem-based learning: Using students' questions to drive knowledge construction. Science Education, 88(5), 707-727.

Clark, B. (2002). Growing up Gifted, (6. Bask1), Pearson Education, Inc., Upper Saddle River, New Jersey.

Cropley, A. J., Urban, K. K. (2000) Programs and Strategies for Nurturing Creativity. In Heller, K. A., Mönks, F. J., Sternberg, R. J., Subotnik, R. F. (Eds.), International Handbook of Giftedness and Talent, 2, Elsevier, Oxford, UK, pp 485-498

Deveci, H. (2002). "Sosyal Bilgiler Dersinde Problem Dayalı Öğrenmenin Öğrencilerin Derse İlişkin Tutumlarına, Akademik Başarılarına ve Hatırlama Düzeylerine Etkisi”, Eskişehir: Anadolu Üniversitesi Yayınları: 1455 / Eğitim Fakültesi Yayınları: 87.

Harris, K., Marcus, R., McLaren, K. \& Fey, J. (2001). Curriculum materials supporting problem-based teaching, School Science \& Mathematics, 101(6), 310-318

Hmelo-Silver, CE. (2004). Problem-based leaming: What and how do students learn? Educational Psychology Review, 16(3). 235-266.

Johnsen, S.K. \& Ryser, G.R. (1996). An overview of effective practices with gifted students in general-education settings. Journal of Education for the Gifted, 19(4), 379-404

Johnson, D.T., Boyce, L.N., \& Van Tassel-Baska, J. (1995). Science curriculum review: Evaluating materials for high ability learners. Gifted Child Quarterly, 39(1), 36-44.

Kalaycı Ş. (2006). SPSS uygulamalı çok değişkenli istatistik teknikleri. Ankara: Asil Yayın Dağıtım Ltd. 
Karamustafaoğlu, O. \& Yaman, S. (2006). Fen Ĕ̆itiminde Özel Öğretim Yöntemleri. PegemA Yayınc1lık, Ankara.

Koray, Ö., (2003). "Fen Eğitiminde Yaratıcı Düşünmeye Dayalı Öğrenmenin Öğrenme Ürünlerine Etkisi”, Yayınlanmamış Doktora Tezi, Gazi Üniversitesi

Maker, J. (2003). New Directions in Enrichment and Acceleration, In N. Colangelo ve G. Davis (Ed.), Handbook of Gifted Education, (pp. 163 - 173). Boston: Allyn and Bacon.

Marland, S. P. (1972). Education of the gifted and talented. (2 Vols.). Report to congress of the United States Commissioner of Education. Washington, DC: US Government Printing Office.

Ngeow, K., \& Kong, Y. (2001). Learning to learn: Preparing teachers and students for problem-based learning. ERIC Digest. [ED 457 524].

Onargan, T., Cöcen, E. Tatar, Ç., Köktürk, U., Mordoğan, H. \& Batar, T. (2004). Maden mühendisliği eğitiminde probleme dayalı öğretim için yapılanma modeli. 1. Ulusal Mühendislik Kongresi Bildiriler Kitabı.

Parim, G. (2002). "Problem Tabanlı Ögretim Yaklaşımı ile DNA, Kromozom ve Gen Kavramlarının Öğrenilmesi”, Yayınlanmamış Yüksek Lisans Tezi, Marmara Üniversitesi.

Piirto, J. (2004). Understanding Creativity. Scottsdale, AZ: Great Potential Press, Inc.

Pyrty, M. (2000). Talent Development in Science and Technology, In K. Heller, F. Mönks, R. Sternberg, R. Subotnik (Eds). International Handbook of Giftedness and Talent. s. 427-437 Pergama Publications.

Roschelle, J. (1999). Transitioning to professional practice: A Deweyan view of five analyses of problem-based learning, Discourse Processes, 27 (2).

Sönmez, D. \& Lee, H. (2003). Problem-based leaming in science. (ERIC Document Reproduction Service No. ED482724).

Sönmez, V. (2007). Program Geliştirmede Öğretmen Elkitabı. 13. Baskı. Anı Yayıncılık. Ankara

Stepanek, J. (1999). Meeting the needs of gifted students: Differentiaing mathematics and science instruction. ERIC EC 307996, ED 444306. Erişim:12 Mart 2008

Sungur, N. (1997). Yaratıcı Düşünme, İkinci Baskı, İstanbul: Evrim Yayınevi 
Şenocak, E. (2005). "Probleme Dayalı Öğrenme Yaklaşımının Maddenin Gaz Hali Konusunun Öğretimine Etkisi Üzerine Bir Araştırma”, Yayınlanmamış Doktora Tezi, Atatürk Üniversitesi, Erzurum.

Tavukçu, K. (2006). "Probleme Dayalı Öğrenmenin Öğrenme Ürünlerine Etkisi” Yayınlanmamış Yüksek Lisans Tezi, Zonguldak Karaelmas Üniversitesi.

Torrance, E. P. (1966). Torrance Test of Creative Thinking norms technical manual research edition. Personel Pres Inc., New Jersey

VanTassel-Baska, J. (2000). Theory and Research on Currriculum Development for the Gifted. (Ed: K. Heller, F. Mönks, R. Sternberg, R. Subotnik) International Handbook of Giftedness and Talent. 345-365. Pergama Publications.

VanTassel-Baska, J. (2003). Curriculum planning and instructional design for gifted learners.

Denver, CO: Love Publishing Company.

Watters, J.J. (2004). In pursuit of exellence in science. Australasian Journal of Gifted Education. 13 (2), s. 41-53.

Yaman, S. \& Yalçın, N. (2005). Fen eğitiminde probleme dayalı öğrenme yaklaşımının problem çözme ve öz-yeterlik inanç düzeylerinin gelişimine etkisi. Hacettepe Üniversitesi Eğitim Fakültesi Dergisi. 29: 229-236.

Yaman, S. (2003). "Fen Bilgisi Eğitiminde Probleme Dayalı Öğrenmenin Öğrenme Ürünlerine Etkisi,” Yayınlanmamış Doktora Tezi, Gazi Üniversitesi EBE, Ankara

Yıldırım, A. ve Şimşek, H. (2008). Sosyal Bilimlerde Nitel Araştırma Yöntemleri. Ankara: Seçkin Yayıncılık.

\section{$\underline{E k .1 .}$}

$\underline{\text { Problem Senaryosu }}$

İlk Problem Cümlesi

Yerel bir elektrik şirketinde işe yeni alınmış bir elemansınız. Şirketin oryantasyon programını tamamladıktan sonra ilk göreviniz şehrin merkezinde bir eğlence merkezi tasarlaması istenen bir takımın parçası olarak çalışmak. Bu proje hem devlet hem de belediye tarafindan desteklenmekte. Sizin göreviniz yeni merkez için elektrik kaynaklarının yeterli ve doğru olarak planlandığından emin olmak. Yeni merkez tüm vatandaşlara (özür grupları da dahil) hizmet verecektir. Ayrıca sizin merkez için kapsamlı bir yedek plan da geliştirmeniz gerekmekte. Üniversitede aldığınız eğitim elektrik değil şehir planlaması ve yönetimi üzerine. 